\title{
HRM TRANSITION IN INDONESIAN COMPANIES FOLLOWING THE ASIAN FINANCIAL CRISIS
}

\begin{abstract}
The paper reports on a study of human resource management practices in seven large Indonesian Companies following the Indonesian financial crisis which began in 1997. Current practices reported by company staff were considered against a conceptual framework representing the stages of Personnel Administration, Human Resource Management, and Strategic Human Resource Management. Results provide clear evidence of practices in each stage occurring simultaneously. The data in one company, reported here, challenges the more usual notion of an integrated and linear HRM system and is replaced by a combination of linear and non- linear elements. There was with clear evidence of transition and adaptation to the new post-crisis situation based on the strategic intent of the individual firm.
\end{abstract}

\section{INTRODUCTION}

In achieving and maintaining a competitive edge in a rapidly changing world, organizations have to face some many challenges. These include managing growth and change in an increasingly global marketplace (Lajara, Lillo \& Sabater, 2002; Lawler III \& Mohrman, 2003; Gubman, 2004). Simultaneously, pressures from competitors, shareholders and customers require companies to create services and processes ahead of the competition (Brockbank, 1999). This paper will focus on the challenges Indonesian organizations face in dealing with their people as human resources, particularly in relation to the implementation of strategic human resource management in organisations. Following the 1997 Asian financial crisis, Indonesian companies faced particular challenges as they sought to respond to global markets and sustain their companies' viability.

This paper seeks to identify how some large Indonesian companies are responding to this challenge from a human resource perspective. It seeks to identify the barriers and enablers influencing the transition from personnel administration to strategic human resources management in these large Indonesian companies. The paper begins by outlining the human resource literature which has established the conceptual framework used in this study. Then the chosen methodology is described
Maureen Bickley and Nurianna Thoha, Curtin University of Technology, Australia

together with the processes for data collection and analysis used in this study. Indicative results are provided for all companies with the focus on the 'leader' company $\mathrm{C}$. The paper then provides a discussion of these results which challenge traditional notions of an integrated human resource management system.

\section{LITERATURE REVIEW}

The challenges faced by Indonesian companies following the financial crisis of 1997 focussed companies' attention on urgent survival strategies. In the 1990's literature in human resource management (HRM), the better use of human resources to achieve strategic competitive advantage was a central theme (Beer, 1997; Ehrlich, 1997; Mohrman \& Lawler, 1997; Ulrich, 1997).

"There is little question that human resource management is undergoing profound change as the 20th century draws to a close. What are the forces for change? Where are human resource management and the human resource functions going? What are the obstacles to getting there?" (Beer, 1997, p.49).

Whilst the introduction of HRM to replace the older Personnel Administration (PA) was the focus in the 1980 's, by the late 1990's writers focussed on the need to move the approach even further. Smilansky (1997) suggests that a change of focus and scope of human resource management was needed, from a more service delivery approach provided by a large number of relatively junior practitioners, to a more strategic consultancy service, in which the human resource function provides guidance and advice to line management. Tracey and Nathan (2002) also propose a role for human resource management in the organization in addition to its existing functions. The new role becomes one of integrating people, policies, and cultures. Here, strategic human resource management (SHRM) would provide an integrated and coherent strategic system. Overall, they suggest, human resource professionals will become internal consultants and strategic partners rather than mere arbiters of legal practice. Turning to SHRM techniques to pave the way for organisational transformation and effectiveness enables businesses to navigate periods of rapid change (Buyens \& De Vos, 2001, Boxall \& 
Purcell, 2000, Truss \& Gratton 1994, Lundy, 1994).

As pointed out by Bresnan (1993), Indonesia was one of the least known countries until the Asian financial crisis in 1997. Since that time Indonesia has become known for its almost continuous political, social, and economic crisis. Hill (2000) asserts that the impact of the Asian financial crisis on the Indonesian economy is one of the most extraordinary events in the late twentieth century -"a country which, with very little prior warning, experienced a quite catastrophic economic collapse" (Hill 2000, p.xiv). The Indonesian economy had been growing at an annual average rate of 6.5 per cent for three decades and faster in the 1990s, and most of its social indicators had shown significant improvement. Then, it suddenly faced a major crisis which was indicated by its GDP contracting by almost 14 per cent in one year (Hill 2000). He continues that, "by early 1998 it was apparent that it was by far the worst affected of Asia's crisis economies - a sharper economic decline, higher inflation, more serious financial collapse, and of course deeper political and social problems. As we approach the new millennium, Indonesia's economic future is again gloomy and uncertain" (Hill 2000, p.xiv).

Butler and Lee (2003) suggest that since the Asian financial crisis has forced firms in these countries to re-examine their activities, now is an interesting time to examine HRM in Asian countries. This present research was conducted in seven large Indonesian companies looking at their human resource practices. Most of the previous literature on Indonesian HRM focussed on labour economics and macro level human resource development in Indonesia (Bennington \& Habir 2003). Some surveys on particular human resource management practices had been conducted in Indonesia such as: performance appraisal practices by Milliman et al (2002), training and development practices by Drost et al (2002), the role of human resource management by Bowen et al (2002), international compensation practices by Lowe et al (2002) and personnel selection practices by Huo et al (2002). None of these focussed on company level practices across the full range of PA, HRM and SHRM activities to identify whether such practices within a single company were fully integrated or dispersed across multiple approaches.

Focusing on human resource management in Indonesia is critical since Indonesia is a country with the fourth largest population in the world (Khoo 1998; Manning 1998) and with enormous diversity in its demographic makeup (Gesteland 1996). Its population of almost 210 million (Hill 2000) includes Javanese,
Bataks, Chinese, and 300 other ethnic groups (Gesteland 1996), each with its own separate language (Vickers 1997). The country has had a tradition of hierarchical management with considerable emphasis on the more traditional Personnel Administration.

\section{METHODOLOGY AND RESEARCH DESIGN}

The research aimed to investigate the activities related to the personnel administration/human resource management/ strategic human resource management as reported in individual company settings. The study was conducted in seven large Indonesian Companies, focusing on the development of theory through a case study approach (Eisenhardt, 1989; Yin, 1994). The study Companies are referred to as Company A, B, C, and S/G Companies (which consist of Company D, E, F, and G). Company A is a Holding Company of twenty six Branch Offices and sixteen Subsidiaries. The business scope of the Company is highly diverse, including Agro-Industry, Pharmacy and Medical Equipment, Trading, and Property. Company B is a Telecommunication Company producing a wide range of telecommunication equipment and providing telecommunication services across the country. Company $\mathrm{C}$ is an Electricity Company which has SBUs and Subsidiaries all over Indonesia. The S/G Companies comprise three Sugarcane Companies and one Ethanol Company.

A constructivist paradigm was adopted to guide the research methodology since the focus was on the participants' construction of their real world setting. This "paradigm assumes a relativist ontology (there are multiple realities), a subjectivist epistemology (knower and subject create understandings), and a naturalistic (in the natural world) set of methodological procedure. Findings are usually presented in term of the criteria of grounded theory" (Denzin \& Lincoln, 1994, p.13-14).

This study uses the generative aspects of grounded theory (Glaser \& Strauss, 1967) - both purposive theoretical sampling and content analysis. Grounded Theory, as describes by Whiteley (2000a) was used. "Grounded Theory (Glaser \& Strauss, 1967) is a field of research method that seeks to discover respondents' versions of social phenomena through the act of emergence. It can use quantitative or qualitative data but concepts and theories that emerge are not arrived at by statistical methods. Basically data analysis in grounded theory is qualitative. For example, an examination of timesheets could show a severe level of lateness in a department. These quantitative data need to be interpreted by the people involved. They need to give the researcher their 'theories' about what is hap- 
Journal of Global Strategic Management | V. 1 | N. 1 | 2007-June | isma.info | 75-86 | DOI: 10.20460/JGSM.2007118716

EXHIBIT 1: SUMMARY OF THE CHARACTERISTICS OF ELEMENTS IN COMPANY A, B, C, AND SUGAR GROUP

\begin{tabular}{|c|c|c|c|c|}
\hline \multirow[b]{2}{*}{ ELEMENTS } & \multicolumn{4}{|c|}{ COMPANY } \\
\hline & A & B & $\mathrm{C}$ & SG \\
\hline \multicolumn{5}{|l|}{ PA } \\
\hline 1. Grading System Administration & $\mathrm{XT}$ & XT & XT & $\mathrm{XT}$ \\
\hline 2. Compensation System Administration: & $\mathrm{X}$ & $\mathrm{X}$ & $\mathrm{X}$ & $\mathrm{X}$ \\
\hline - Payment Procedure & $\mathrm{X}$ & $\mathrm{X}$ & $\mathrm{X}$ & $\mathrm{X}$ \\
\hline - Retirement Payment & $\mathrm{X}$ & $\mathrm{X}$ & $\mathrm{X}$ & $\mathrm{X}$ \\
\hline - Overtime Payment & $\mathrm{X}$ & 0 & 0 & $\mathrm{X}$ \\
\hline - Payment Deductions & $\mathrm{X}$ & $\mathrm{X}$ & $\mathrm{X}$ & $\mathrm{X}$ \\
\hline - Payment of Bonus, Benefits, and Incentives & $\mathrm{X}$ & $\mathrm{X}$ & $\mathrm{X}$ & $\mathrm{X}$ \\
\hline - Payment of Insurance, Pension, Tax & $\mathrm{X}$ & $\mathrm{X}$ & $\mathrm{X}$ & $\mathrm{X}$ \\
\hline - Financial Report & 0 & 0 & $\mathrm{X}$ & $\mathrm{X}$ \\
\hline 3. Training Administration & $\mathrm{X}$ & $\mathrm{X}$ & $\mathrm{X}$ & $\mathrm{X}$ \\
\hline - In house Training & $\mathrm{X}$ & $\mathrm{X}$ & $\mathrm{X}$ & $\mathrm{X}$ \\
\hline 4. Basic Use of IT and Data & $\mathrm{X}$ & $\mathrm{X}$ & $\mathrm{X}$ & $\mathrm{X}$ \\
\hline 5. Other Personnel Procedures and Roles & $\mathrm{X}$ & $\mathrm{X}$ & $\mathrm{X}$ & $\mathrm{X}$ \\
\hline - Medical Administration & $\mathrm{X}$ & $\mathrm{X}$ & $\mathrm{X}$ & $\mathrm{X}$ \\
\hline - Attendance \& Discipline & $\mathrm{X}$ & $\mathrm{X}$ & $\mathrm{X}$ & $\mathrm{X}$ \\
\hline - Accident \& Insurance & 0 & 0 & 0 & $\mathrm{X}$ \\
\hline - Leave administration & 0 & $\mathrm{X}$ & $\mathrm{X}$ & $\mathrm{X}$ \\
\hline 6. HR Division History & 0 & XT & 0 & 0 \\
\hline 7. Human Resource Planning & 0 & 0 & 0 & $\mathrm{X}$ \\
\hline 8. Part Time Employee Administration & 0 & 0 & 0 & $\mathrm{X}$ \\
\hline - Daily Workers Administration & 0 & 0 & 0 & $\mathrm{X}$ \\
\hline - Seasonal Workers Administration & 0 & 0 & 0 & $\mathrm{X}$ \\
\hline \multicolumn{5}{|l|}{ HRM } \\
\hline 1. Organization Design & $\mathrm{XT}$ & 0 & 0 & 0 \\
\hline 2. Competency Development & 0 & XT & 0 & 0 \\
\hline 3. Job Analysis and Job Description Development & 0 & 0 & XT & 0 \\
\hline 4. Personnel Roles and Strategy in the Companies' Strategy & 0 & 0 & 0 & $\mathrm{X}$ \\
\hline 5. Admin Consistency & 0 & 0 & 0 & $\mathrm{X}$ \\
\hline 6. Human Resource Planning & $\mathrm{XT}$ & XT & XT & 0 \\
\hline 7. Recruitment Method and Selection process & $\mathrm{X}$ & $\mathrm{X}$ & $\mathrm{X}$ & $\mathrm{X}$ \\
\hline 8. Orientation and Probation Design & $\mathrm{X}$ & 0 & 0 & $\mathrm{X}$ \\
\hline 9. On the Job Training & $\mathrm{X}$ & 0 & $\mathrm{X}$ & $\mathrm{X}$ \\
\hline $\begin{array}{l}\text { 10. Compensation System: Salary Determination, } \\
\text { Increase Review, Comparison. } \quad \text { WPS design: Benefit and Bonus }\end{array}$ & $\mathrm{X}$ & $\mathrm{X}$ & $\mathrm{X}$ & $\mathrm{X}$ \\
\hline 11. Performance Management & XT & XT & XT & XT \\
\hline 13. Training Provision & XT & $\mathrm{X}$ & XT & $\mathrm{X}$ \\
\hline 14. Career Progression & XT & $\mathrm{X}$ & XT & $\mathrm{X}$ \\
\hline 15. Procedural Communication & $\mathrm{X}$ & $\mathrm{X}$ & $\mathrm{X}$ & $\mathrm{X}$ \\
\hline 16. Motivation & $\mathrm{X}$ & $\mathrm{X}$ & $\mathrm{X}$ & $\mathrm{X}$ \\
\hline 17. Developing IT & $\mathrm{X}$ & $\mathrm{X}$ & 0 & 0 \\
\hline 18. HR Information System & 0 & 0 & $\mathrm{X}$ & 0 \\
\hline 19. Industrial Relations & $\mathrm{X}$ & $\mathrm{X}$ & $\mathrm{X}$ & $\mathrm{X}$ \\
\hline \multicolumn{5}{|l|}{ SHRM } \\
\hline 1. Organization Development: Future Planning & $\mathrm{X}$ & 0 & $\mathrm{X}$ & 0 \\
\hline 2. Competency Assessment & $\mathrm{X}$ & $\mathrm{X}$ & $\mathrm{X}$ & 0 \\
\hline 3. Business Strategy Link with HR strategy & $\mathrm{X}$ & 0 & 0 & 0 \\
\hline 4. System Development & 0 & $\mathrm{X}$ & $\mathrm{X}$ & 0 \\
\hline 5. Preparation for SHRM Application & $\mathrm{X}$ & $\mathrm{X}$ & $\mathrm{X}$ & 0 \\
\hline 6. Organization Culture and HR Policy Analysis & 0 & $\mathrm{X}$ & $\mathrm{X}$ & 0 \\
\hline 7. Recruitment Strategy & $\mathrm{X}$ & $\mathrm{X}$ & $\mathrm{X}$ & $\mathrm{X}$ \\
\hline 8. Strategic Training and Development & $\mathrm{X}$ & 0 & $\mathrm{X}$ & 0 \\
\hline - Formal Education & 0 & $\mathrm{X}$ & $\mathrm{X}$ & 0 \\
\hline 9. Strategic Performance Management & $\mathrm{X}$ & $\mathrm{X}$ & $\mathrm{X}$ & $\mathrm{X}$ \\
\hline 10. Strategic Compensation Decision: & $\mathrm{X}$ & $\mathrm{X}$ & $\mathrm{X}$ & $\mathrm{X}$ \\
\hline - Performance Merit & $\mathrm{X}$ & 0 & 0 & 0 \\
\hline - Performance Based Benefit & 0 & $\mathrm{X}$ & 0 & 0 \\
\hline - Reward, Bonus, Performance Benefit, Award & 0 & 0 & $\mathrm{X}$ & 0 \\
\hline - Bonus, Facilities, Benefits, Allowances & 0 & 0 & 0 & $\mathrm{X}$ \\
\hline 11. Preparing Future Leaders: & $\mathrm{X}$ & 0 & $\mathrm{X}$ & 0 \\
\hline - Career for GM & $\mathrm{X}$ & 0 & 0 & 0 \\
\hline - Branch Manager & 0 & 0 & $\mathrm{X}$ & 0 \\
\hline 12. Personnel Information System & 0 & $\mathrm{X}$ & 0 & 0 \\
\hline - HR and Library Websites & 0 & $\mathrm{X}$ & 0 & 0 \\
\hline 13. Strategic Communication & $\mathrm{X}$ & $\mathrm{X}$ & $\mathrm{x}$ & 0 \\
\hline 14. Motivation & $\mathrm{X}$ & 0 & $\mathrm{x}$ & $\mathrm{X}$ \\
\hline
\end{tabular}


pening. These theories are qualitative in nature and they need to be analyzed qualitatively" (Whiteley, 2000a, p.9).

The research design had three stages. Following a literature study, preliminary fieldwork was conducted and the results were analyzed to confirm the research question and method. The second stage was data collection; both primary data (interviews) and secondary data (HR documents) were collected. The interview data were transcribed and analyzed, using content analysis (Holsti, 1969). Qualitative document analysis was also conducted for the HR documents following Altheide (1996). This led to the third stage of developing and discussing findings within the context of theoretical sensitivity.

The data were collected by using semi-structured interviews (King, 1994) in Bahasa Indonesia - the national language. This approach was chosen since it enabled the researcher to ask open-ended questions and allowed the researchers more freedom to explore and probe issues (May, 1997). This format gives respondents the opportunity to tell their stories based on their own experiences, since this study follows the tradition of 'giving voice' to respondents (Charmaz, 2000). Eighty-eight face to face interviews were conducted and recorded. The interviewees were all practitioners and comprised the HR Director, HR Division Head, HR Manager, Line Manager, HR Supervisors, and HR staff of the seven Indonesian companies.

"Content analysis is the process of identifying, coding, and categorizing the primary patterns in the data. This means analyzing the content of interviews and observations." (Patton, 1990, p.381). Content analysis following Grounded Theory protocols was used. The categories and concepts developed were subjected to a process of constant comparison and questioning to ensure understanding was robust. This process also enabled the links between various categories and concepts to be explored within each company rather than assumed. The data were coded using an open-coding process consistent with a grounded theory approach (Strauss \& Corbin, 1990). The coding was conducted with no predetermined codes and this allowed the preliminary codes to emerge from the data (Glaser, 1992). The codes were then reconsidered so that the categories were compared and integrated in a way that reflects theoretical sensitivity in developing the concepts. Thus, the coding process goes through four steps: code, categorize, apply constant comparison/constant questioning, and finally conceptualize the idea.

\section{DISCUSSION OF FINDINGS}

Three clear super categories of practice were identified following content analysis processes: PA (Personnel Administration), HRM (Human Resource Management), and SHRM (Strategic Human Resource Management) practices which resonated with the HR literature. PA was defined as the basic administrative activities such as record keeping (attendance, leave records) company training, salary computation and other short term task oriented activities (Whiteley, Cheung and Zhang, 2000). HRM is the integrated system for managing human resources with an emphasis on full utilization of these resources (Guest, 1987). It reflects a medium term view, is job related and has a functional focus. SHRM is when human resources are fully integrated into the strategy and strategic needs of the organization. Being long term and developmental it coheres across hierarchy and policy areas (Guest, 1989). Evidence of Transition (Whiteley, Cheung and Zhang, 2000) was found between these super categories as organizations were moving between PA and HRM, and HRM and SHRM

Exhibit 1 presents the summary of the characteristics of elements in Company A, B, C, and the Sugar Group Companies. It shows that PA has two characteristics. The first includes Foundational Administration Activities. These activities are static, with no expectation of transition, and mainly deal with basic administration functions. They are performed in the Companies as supporting functions $(\mathrm{X}=$ present, $0=$ not present in Exhibit 1). Examples of these activities are Compensation System Administration, Training Administration, Basic Use of IT and Data, and Other Personnel Procedures and Roles. These activities have short-term view, task oriented and reactive. The second characteristic includes those PA elements that in the Companies and the literature have progressed toward HRM. In other words, these elements are in a transition period and they are moving from PA towards HRM (see mark XT in Exhibit 1). Examples of these elements are Grading System Administration and a code we called HR Division History (only in Company B) where participants focused on the development of the HR Division's functions in Company B.

HRM in Exhibit 1 also has two characteristics. The first includes Foundational HRM Activities. These activities are static and there is no expectation of transition (see mark $X$ in exhibit1). Examples of these activities are Recruitment Methods and Selection Process, Orientation and Probation Design, Compensation System, and Industrial Relations. These activities have a medium-term view, are job related and have a functional focus. The second char- 
acteristic includes HRM activities that in Companies and the literature have progressed toward SHRM. In other words, these activities are in a transition period and they are moving from HRM toward SHRM (see mark XT in exhibit 1). Examples of these activities occur in seven areas: Organizational Design; Competency Development; Job Analysis and Job Description Development; Human Resource Planning; Performance Management; Training Provision and Career Progression. All companies had commenced the transition from HRM to SHRM in the areas of HR Planning and Performance Management

Finally Exhibit 1 shows that as yet Indonesian companies have adopted only foundational SHRM Activities. Examples of these activities are Organization Development: Future Planning, Competency Assessment, System Development, Preparation for SHRM Application, Recruitment Strategy, Strategic Training and Development, Strategic Performance Management, Strategic Compensation Decision, Preparing Future Leaders, Strategic Communication, and Motivation. These activities have a long-term view, are integrated and developmental in focus.

\section{The Elements Exhibiting Transition}

There is a sense of movement on the elements marked with XT. This came as activities were moving across boundaries, for instance PA activities began to transform into HRM, and HRM activities began to transform into SHRM. These we concluded demonstrated the concept of 'transition'. Furthermore, the data show a combination of Linear and Non-Linear relationships but the sense is one of adaptation. The linear relationship is found in the PA domain while the non-linear relationship, which is characteristic of complex adaptive systems (CAS), is found in the HRM and SHRM domains. The elements that are in a transition period, from PA toward HRM, and from HRM toward SHRM were identified as shown in Exhibit 2.

\section{The Elements in Transition from PA toward HRM}

In all of the study organizations, the grading system was undergoing a process of transition. The Grading System Administration element is categorized as PA practice since it classifies the employees into a hierarchical system. However the system was further developed to include a company-based status symbol based on qualifications which is embedded in each level, and used to determine the salary, bonus, facilities, benefits, allowances, training and development, and career of the employees. For example, lower level employees get a different bonus percentage (of the salary) from higher-level employees. They can not get the same facilities, benefits and allowances as higher level of employees. Moreover, lower level employees can not participate in training and development opportunities which are only available for higher level employees, and they also can not be promoted to certain levels of jobs. Therefore, the Grading System Administration is categorized as an element which is in transition from PA toward HRM.

\section{The Elements in Transition from HRM toward SHRM}

The elements in Transition from HRM toward SHRM can be seen in exhibit 2. Whilst there was evidence of transition in all companies this was most extensive in Company C and very limited in the Sugar Group companies. Some examples of findings which demonstrate

\section{EXHIBIT 2: ELEMENTS DEMONSTRATING MOVEMENT (TRANSITIONS) IN COMPANY}

\section{A, B, C, AND SUGAR GROUP COMPANIES}

\begin{tabular}{|c|c|c|c|c|}
\hline \multirow[b]{2}{*}{ SUPER CATEGORY } & \multicolumn{4}{|l|}{ COMPANY } \\
\hline & A & B & $\mathrm{C}$ & SG \\
\hline \multirow{2}{*}{$\begin{array}{l}\text { PA } \\
\text { in transtion } \\
\text { toward } \\
\text { HRM }\end{array}$} & $\begin{array}{l}\text { Grading } \\
\text { System } \\
\text { Administration }\end{array}$ & $\begin{array}{l}\text { Grading } \\
\text { System } \\
\text { Administration }\end{array}$ & $\begin{array}{l}\text { Grading } \\
\text { System } \\
\text { Administration }\end{array}$ & $\begin{array}{l}\text { Grading } \\
\text { System } \\
\text { Administration }\end{array}$ \\
\hline & & & & \\
\hline \multirow[t]{5}{*}{$\begin{array}{l}\text { HRM } \\
\text { intransition } \\
\text { toward SHRM }\end{array}$} & Organization Design & $\begin{array}{l}\text { Competency } \\
\text { Development }\end{array}$ & $\begin{array}{l}\text { Job Analysis and } \\
\text { Job Description } \\
\text { Development }\end{array}$ & \\
\hline & $\begin{array}{l}\text { Human Resource } \\
\text { Planning }\end{array}$ & $\begin{array}{l}\text { Human Resource } \\
\text { Planning }\end{array}$ & $\begin{array}{l}\text { Human Resource } \\
\text { Planning }\end{array}$ & \\
\hline & $\begin{array}{l}\text { Performance } \\
\text { Management }\end{array}$ & $\begin{array}{l}\text { Performance } \\
\text { Management }\end{array}$ & $\begin{array}{l}\text { Performance } \\
\text { Management }\end{array}$ & $\begin{array}{l}\text { Performance } \\
\text { Management }\end{array}$ \\
\hline & Training Provision & & Training Provision & \\
\hline & Career Progression & & Career Progression & \\
\hline
\end{tabular}


the process and nature of transition in the 'leader', Company $\mathrm{C}$, is provided below.

The Job Analysis and Job Description Development activity in Company $\mathrm{C}$ was categorized as HRM practice but showed strong evidence of transition. This Company was clearly trying to manage its organization better by conducting training for staff in developing job analysis and job descriptions which are to be used to adjust to the new organization structure. It is seeking to develop this organizational competence across the organization so that it can be used proactively and rapidly as the company adapts to future changes. It is therefore linked clearly to the SHRM practice of Organizational Design and Development.

Company C's Human Resource Planning activity is also categorized into HRM practice since it is developed for a medium term plan (five-year plan) and focused on improving the composition of employees based on their education qualification. Its HR Planning activities are conducted to prepare the Company for the application of SHRM and to support its future planning for its Organization Design and Development. Meanwhile, the Organization Design and Development: Future Planning element itself is categorized as SHRM practice since it will develop the organization in such a way that the Company is adaptive and flexible to the environmental changes and effective in achieving the Company's objectives. Therefore both Job Analysis and Job Description Development and Human Resource Planning elements are categorized as the elements which show clear evi- dence of being in the transition from HRM toward SHRM (see exhibit 2).

The relationships between the various practice elements were described by participants during the interview. The researchers sought to identify participants' (practitioners) construction on these relationships rather than assume relationships. From the analysis of these data complex interactions between elements were identified and mapped. This analysis process identified linear and non- linear relationships in the case study companies.

\section{Linear Models Evident in the PA Domain}

The data of the PA functional activities in all Companies followed straightforward linear relationships. Exhibit 3 is an example of a linear model in the PA domain within Company $\mathrm{C}$ and is shown using Indonesian names for terms. This exhibit shows for example that the Compensation System Administration element, which includes annual leave and 'big' (trans: long service leave) leave payments, support people payment, 'experts' (trans: pensioners returning to advise company) payment, payment of benefits, and payment deductions, follows a payment procedure which involves a multi level process. The process requires that each payment request needs to be sent from the HR Department to the Finance Manager, then the Finance Manager makes a 'recapitulation' (trans: reconciliation to staff records) of the payment for each Directorate and a transfer receipt. The pay-

\section{EXHIBIT 3: A LINEAR MODEL OF PA PRACTICE IN COMPANY C}

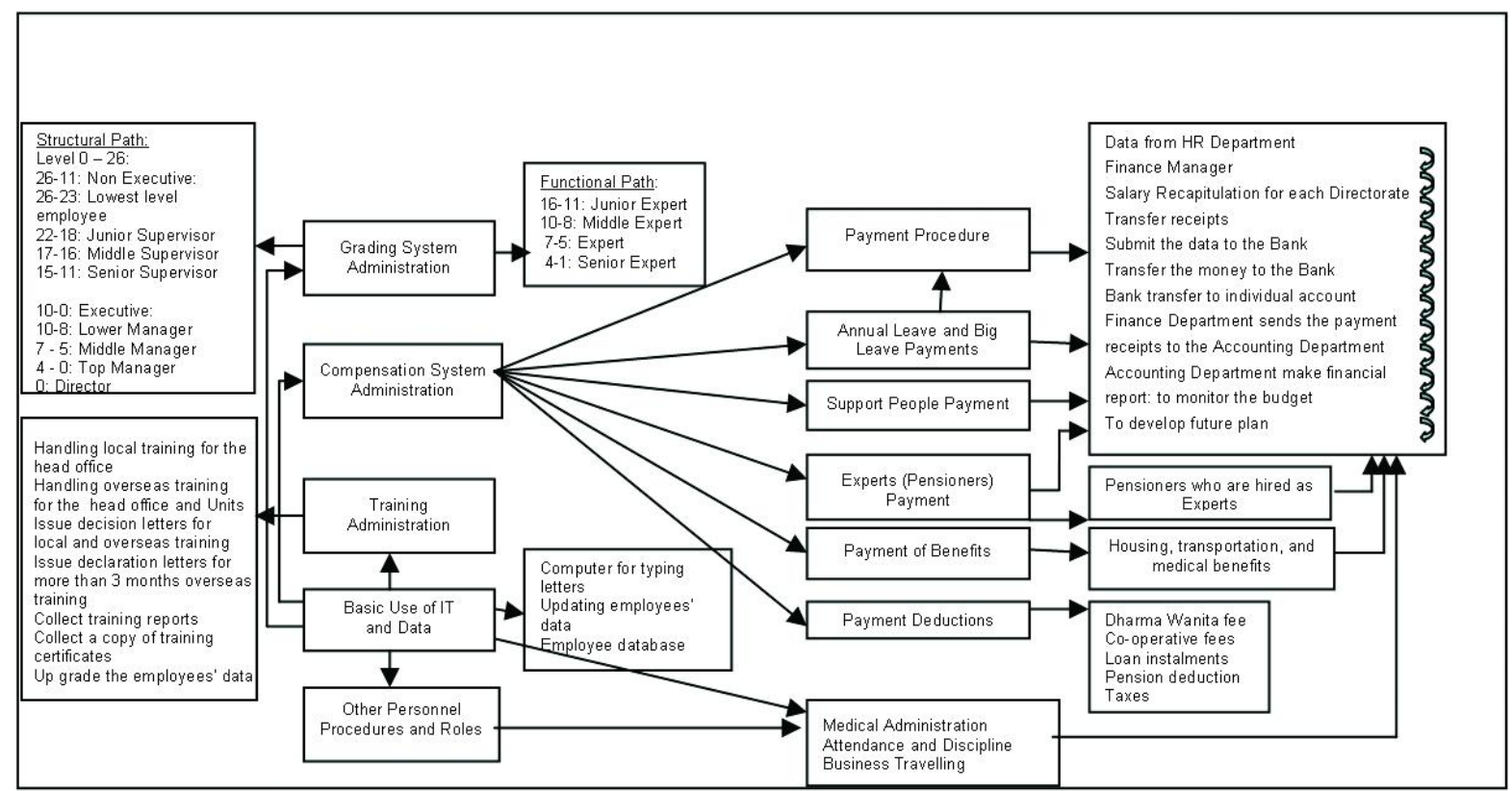


ment is done by transferring the money to the respective account. The payments that occurs for other elements, such as training, medical, and business traveling follow the same highly structured payment process.

All these administrative practices utilize IT and HR Data in conducting their activities and this IT element is shown to be functionally connected to other elements. Therefore, it can be said that PA practice in Company $\mathrm{C}$ follows a linear model since the links among the elements in PA domain show linearity. This reflects the work of Lewin and Regine's (2003) who identified management practice as being wither linear or non-linear. They explained that in a linear world, things may exist independently of each other, and when they interact, they do so in simple, predictable ways. From this study is it clear that PA in Company $\mathrm{C}$ follows a linear approach. However this linearity in itself does not imply a problem or a sense of this Company being 'out of date'. The simple linear approach is both essential and efficient for most foundational activities in PA for all companies. However it is the quality and availability of IT and HR data which determines the effectiveness of these activities. The major PA problem identified by the company was the lack of an integrated IT and HR data. This had an impact on all PA areas and although no plans were in place to resolve this, participants spoke of this need as a key HR enabler for the future.

\section{Non -Linear Models Evident in the HRM and SHRM Domains}

Human Resource Management (HRM) was hailed as the replacement of Personnel Administration (PA) because it focused on developing an integrated set of policies and practices aimed at fully utilizing the organizations' human resources (Beer, 1997). This focus on integration and coherence of all HR components which characterized this approach would be expected to generate a more complex interactive organizational response. Interviewees (practitioners) in Company $\mathrm{C}$ described how each element was related or not related with other elements. The result of this analysis was a series of element maps shown in Exhibits 4 and 5. The evidence from Company $\mathrm{C}$ of HRM activities combined with the co-existence of transitional (HRM/SHRM) activities provides an example of a somewhat modified complex adaptive system (CAS) (Stacey, 1996).

"At its simplest, an adaptive non linear feedback system is a network consisting of a large number of agents, each of whose behavior is determined by a shared schema consisting of a few rules that are fixed overtime and that apply to all agents without exception....even the simplest adaptive system has some purpose, namely, to perform some task. It follows that... "agents in all adaptive systems adjust their behavior in light of its consequences for their purpose" (Stacey, 1996, p.72).

One characteristic of integrated systems which are adaptive are feedback 'loops' which create connections between many apparently disparate tasks, functions and/or processes. Stacey refers to this as an adaptive non-linear feedback system. Within Exhibit 4 this interconnectedness that takes linear elements and relates them across a spectrum of activities in an integrative way is clearly evident. Within this integrative connectivity, there is a sense of on-going adaptation. For instance Exhibit 4 shows that Procedural Communication needed to adapt to the different discourses and protocols required by, for example, Performance Appraisal, Training, Compensation and other elements. "The concept of Procedural Communication shapes and in turn was shaped by the procedures and discourses of the various functions. This is resonant with CAS in the sense that elements in modified version of complex adaptive systems adjust their behavior in light of its consequences for their purpose" (Thoha and Whiteley, 2005, p9). Elements of the Company aspiring to becoming SHRM i.e. in a process of transition also form part of this interconnectivity and adaptation of procedural communication.

In this Company which we describe as a 'leader' in the introduction of SHRM practices among the case study companies, there is a clear direction being pursued to enable Company $\mathrm{C}$ to take a strategic view of its human resources. This view is based on the need to overcome current barriers to performance and it relies on strong management support as the major enabler. The restructuring of the HR function to achieve a role change (from functional to strategic consultant) is another critical enabler of this change being undertaken but is perceived as being hampered by the lower classification of the HR Director. Perceived barriers to SHRM included poor readiness of some departments for rapid change and the need for employee development especially formal qualifications. The development of English language skills among managers and development of university management partnerships to upgrade future leaders' skills were seen as important initiatives currently being developed. It was notable that the Company participants had readily identified solutions to most barriers and were working to overcome them. 


\section{EXHIBIT 4: HRM PRACTICE IN COMPANY C}

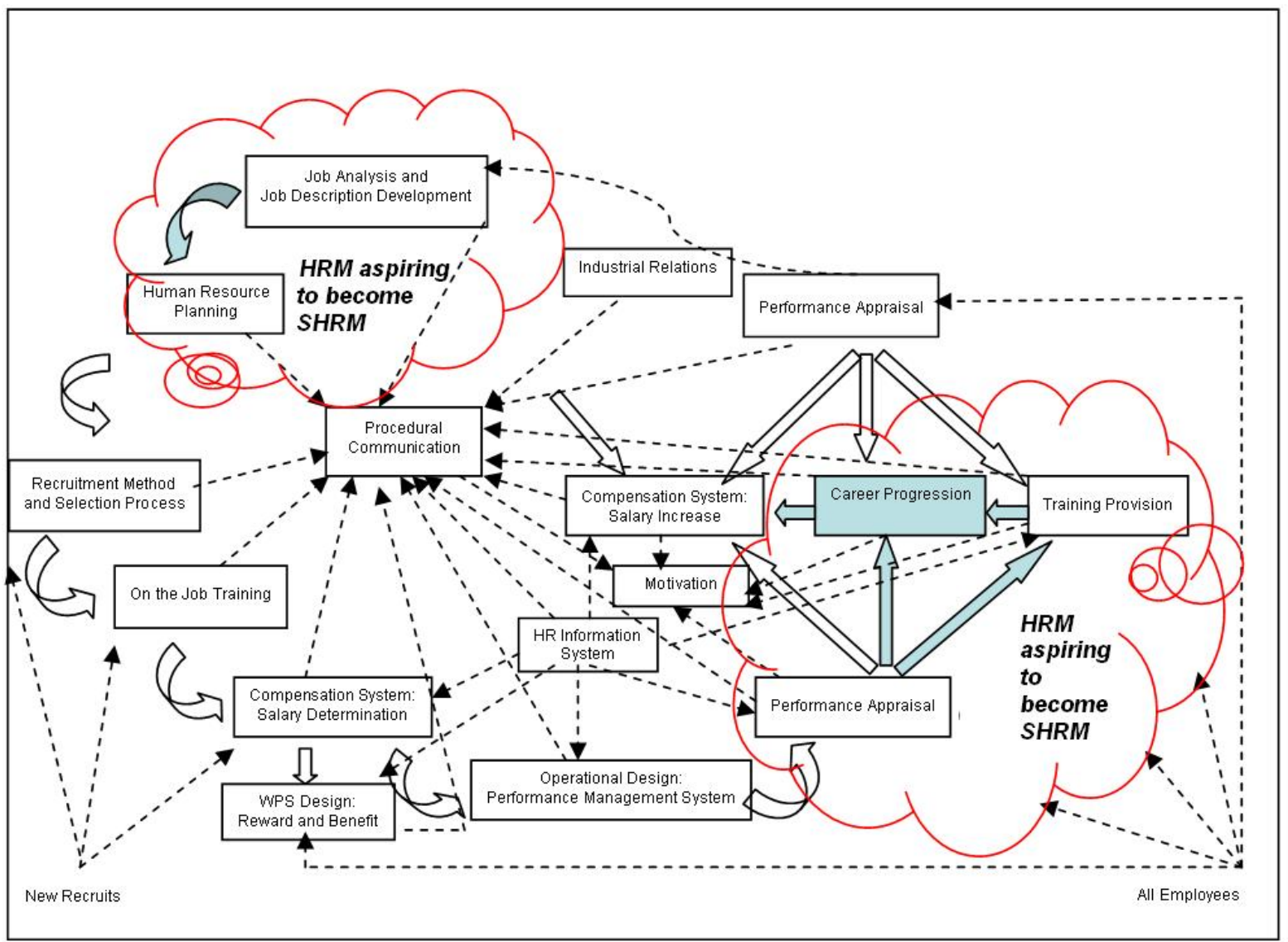

Since the move to a strategic positioning of HR is dependent on clearly articulated strategic directions it is perhaps not surprising that during rapid change there was still some concern within Company $\mathrm{C}$ regarding clarity of future directions. The interaction between the organization's commercial objectives and its community service obligations and the need for Indonesian regional autonomy remains complex and unresolved. The later impacts strongly on the desire to have units take a synergistic approach to future development. It is also not surprising that Strategic Communication becomes a central adaptive inter-connector for SHRM to replace the procedurally based communication in HRM. In Exhibit 5 there is again clear evidence of interconnectedness that takes linear elements and relates them across a spectrum of activities in an integrative way. Here the interconnectivity of Strategic Communication is evident as it adapts in real time to the different discourses and protocols required by Organization Design and Development: Future Plan, Strategic Performance Management and Strategic Compensation Decision for example. The concept of Strategic Communication shapes and in turn was shaped by the discourses of the various func- tions. This again demonstrates how elements in modified versions of complex adaptive systems adjust their behavior in light of its consequences for their purpose (Thoha and Whiteley, 2005).

Achieving the company's strategic intent through the strategic development of its human resources remains a major challenge for this Indonesian company. It has begun to adapt and adopt more 'western' approaches including the building of strategic compensation with individual rewards and non-monetary awards and the use of external consultants to develop its future competency-based structures. It is seeking broader organizational commitment from employees though novel motivation strategies. For example, it has added to its traditional practice of holding religious ceremonies on religious days with whole family outings to fun parks like Fantasyland. Its approach to the implementation of change is identified by several interviewees: "To do the socialization we have three things: ..the first they have to know what is changed and the second is why, and the third is, if it is about the institution, what is the benefit? We have to be able to show that there is a benefit in the change.//(C24,pr.63)//We have three things; the first we make them understand, the second, we 


\section{EXHIBIT 5: SHRM PRACTICES IN COMPANY C}

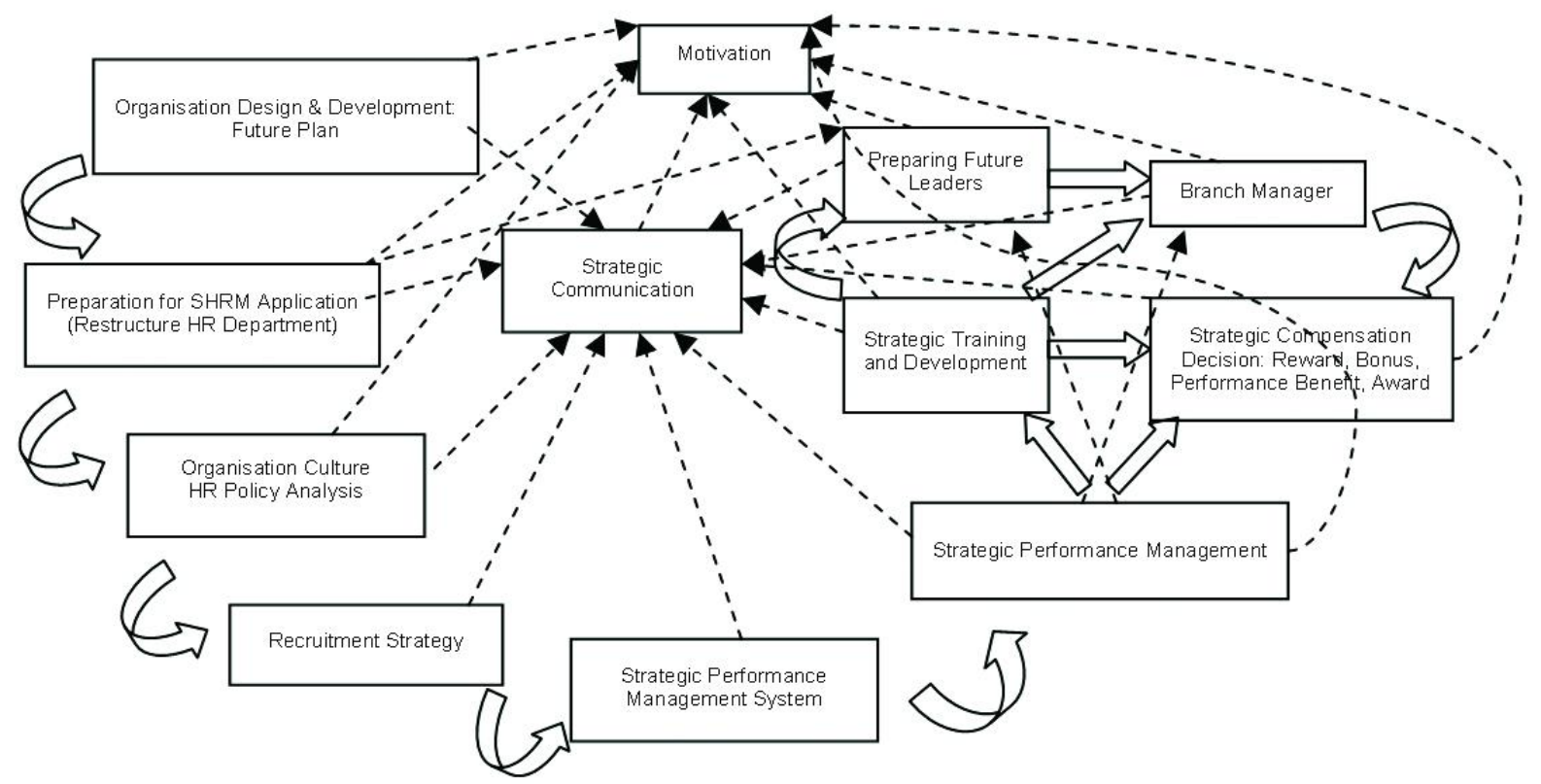

give them facilities for change, the third, we give them an example of benefit and the fourth we give them a reinforcement//(C24,pr.79)"

Dawson (1996) discusses a processual perspective of change which recognizes change as complex and dynamic. "Although it is, in practice, difficult to identify the start or completion of a major change program, it is useful for analytical purposes to identify the period of initial awareness (conception of the need for change) and the period when organizational resources are withdrawn for the management of a particular change programs and the new organizational arrangements form part of daily work routines. Between these two periods lie the complex non-linear processes of change" (Dawson 1996, p64). Within Company C it is clear that the senior practitioners have already reached a level of awareness and that Company resources, including the use of external consultants, are being directed at the SHRM elements. No SHRM elements could be said to be part of daily work routines across the whole organization.

\section{CONCLUSION}

Investigating how large Indonesian companies are performing and reforming human resource practices was made more critical by the Asian financial crisis of 1997. This study gathered qualitative interview data from 88 practitioners within seven large companies to better understand the practices and approaches being used from a practitioner perspective. Data from the face to face interviews were analyzed which identified the existence and co-existence of three super categories of practice, namely PA, HRM and SHRM. From the findings it is clear that there is no simple way to describe 'people practices' in these seven Indonesian companies. Not only are there differences in the findings for each company but the patterns of difference provide a unique opportunity to explore the models of practice; the linear, and complex adaptive non- linear. Based on Stacey's concept of the complex adaptive system, the HRM and SHRM practices conducted in the case Companies can be considered as modified versions of a complex adaptive system.

The research's findings on HR practices in these seven large Indonesian companies in this 'developing' economy, might have expected to find them to be static, simplistic, and linear. But the reality is clearly that there are movements and transitions occurring both within and external to the companies. The linear approach is evident in PA practices but not HRM and SHRM practices. Within the literature traditional HR theory usually proposes a conventional linear approach which is predictable, stable, and controlled to company practices. This is not supported by the findings in this study. Instead the case study Companies provide strong evidence of being more like complex adaptive systems (CAS) with multiple transitions. Organizations which exhibit CAS are characterized by being flexible, innovative, creative, adaptable, and able to dismantle the system if necessary. This study shows that such organizations are not confined to the 'more developed' world. It also showed that the progress to a more strategic approach within 
the company was based on the support and shared views of senior practitioners and the company directors. They were well advanced in seeking external expertise to assist this development and were actively building internal skills and leadership potential. They were adopting an increasingly individualistic approach and strongly supporting English language use and ways to turn their organizational face outwards.

Previous studies of international human resource practices in Indonesia (Milliman et al, 2002, Drost et al, 2002, Lowe et al 2002, Huo et al 2002) have relied on surveys and comparisons of 'spread' and 'use' of preidentified practices. What this study showed is that coexistence and interconnectedness of various processes within companies is more typical. The development of element maps from practitioner evidence rather than models found within the literature provides a richer insight into practices and practice transitions. This would not have been apparent had a standard survey instrument been used for data collection. What is unclear is whether the evidence of adaptation, flexibility and transitions in these companies was the basis for or results from their survival through the first years of the financial crisis. Further investigations of less successful companies might prove useful in clarifying this issue.

\section{REFERENCES}

Altheide, D., L 1996, Qualitative Media Analysis, Sage Publications, Thousand Oaks, Ca.

Beer, M. 1997, The transformation of the human resource function: Resolving the tension between a traditional administrative and a new strategic role, Human Resource Management, vol. 36, no. 1, pp. 49-56.

Bennington, L. and Habir, A. D. 2003, Human resource management in Indonesia, Human Resource Management Review, vol. 13, no. 3, pp. 373-392.

Bowen, D. E., Galang, C. and Pillai, R. 2002, The role of human resource management: An exploratory study of cross-country variance, Human Resource Management, vol. 41, no. 1, p. 103.

Boxall, P. and Purcell, J. 2000, Strategic human resource management: where have we come from and where should we be going, International Journal of Management Reviews, vol. 2, no. 2, pp. 183-203.

Bresnan, J. 1993, Managing Indonesia, Columbia University Press, New York.

Brockbank, W. 1999, If HR were really strategically proactive: Present and future directions in HR's contribution to competitive advantage, Human Resource Management, vol. 38, no. 4, p. 337.ase.

Butler, J. E. and Lee, T. W. 2003, Regional recovery and development: The role of HRM in East and Southeast Asia, Human Resource Management Review, vol. 13, no. 3, pp. 367-372.

Buyens, D. and De Vos, A. 2001, Perception of the value of the HR function, Human Resource Management Journal, vol. 11, no. 3, pp. 70-89. Charmaz, K. 2000, Grounded Theory: Objectivist and Constructivist Method Methods, in N. K. Denzim and Y. S. Lincoln, (eds.), Handbook of Qualitative Research, 2 edn, sage, Thousand Oaks.

Dawson, P. 1996, Beyond conventional change models: A processual perspective, Asia Pacific Journal of Human Resources, Vol. 34, no 2, pp 57-70

Denzin, N. K. and Lincoln, Y. S. 1994, Handbook of Qualitative Research, Sage Publications, Thousand Oaks.

Drost, E. A., Frayne, C. A., Lowe, K. B. and 
Geringer, M. J. 2002, Benchmarking training and development practices: a multi-country comparative analysis, Asia Pacific Journal of Human Resources, vol. 40, no. 1, pp. 81-103.

Ehrlich, C. J. 1997, Human resource management: A changing script for a changing world, Human Resource Management, vol. 36, no. 1, pp. 85-89.

Eisenhardt, K. M. 1989, 'Building theories from case study research', The Academy of Management Review, vol. 14, no. 4, pp. 532-550.

Gesteland, R. R. 1996, Cross-cultural Business Behavior: Marketing, Negotiating and Managing Across Cultures, Handelsh*jskolens Forlag, Copenhagen.

Glaser, B. G. 1992, Basics of Grounded Theory, Sociology Press, Mill Valley, Calif.

Glaser, B. G. and Strauss, A. L. 1967, The Discovery of Grounded Theory; Strategies for Qualitative Research, Aldine Pub. Co., Chicago,.

Gubman, E. 2004, HR Strategy and Planning: From Birth to Business Results, Human Resource Planning, vol. 27, no. 1, pp. 13-23.

Guest, D. E. 1987, Human Resource Management and Industrial Relations, The Journal of Management Studies, vol. 24, no. 5, pp. 503-521.

Guest, D. E. 1989, Personnel And HRM: Can You Tell The Difference? Personnel Management, vol. 21, no. 1, pp. 48-51.

Hill, H. 2000, The Indonesian Economy, 2nd edn, Cambridge University Press, Cambridge/Melbourne. Holsti, O., R 1969, Content Analysis for the Social Sciences and Humanities, Addison-Wesley, Reading, Mass.

Hou, Y. P., Huang, H. J. and Napier, N. K. 2002, Divergence or convergence: a cross-national comparison of personnel selection practices, Asia Pacific Journal of Human Resources, vol. 40, no. 1, pp. 3953.

Kamoche, K. 1994, A critique and a proposed reformulation of strategic human resource management, Human Resource Management Journal, vol. 4, no. 4, pp. 29-43.

King, N. 1994, The qualitative research interview, in C. Cassel and G. Symon, (eds.), Qualitative methods in Organisational Research, Sage Publications,
London, pp. 118-134.

Khoo, E. 1998, Indonesia, in D. G. Jackson and D. A. Wadley, (eds.), Asia Pacific Business Guide 1998, McGraw Hill, Sydney, pp. 98-114.

Lajara, B. M., Lillo, F. G. and Sabater, V. 2002, The role of human resource management in the cooperative strategy process, Human Resource Planning, vol. 25, no. 2, pp. 34-44.

Lawler III, E. E. and Mohrman, S. A. 2003, HR as a strategic partner: what does it take to make it happen? Human Resource Planning, vol. 26, no. 3, pp. 15-29.

Lewin, R. and Regine, B. 2003, The core of adaptive system, in E. Mitleton-Kelly, (ed.) Complex Systems and Evolutionary Perspective on Organisations: The application of complexity theory to organisations, Pergamon, London, pp. 167-183.

Lowe, K. B., Milliman, J., De Cieri, H. and Dowling, P. J. 2002, International compensation practices: a ten-country comparison, Asia Pacific Journal of Human Resources, vol. 40, no. 1, pp. 55-79.

Lundy, O. 1994, From personnel management to strategic human resource management, The International Journal of Human Resource Management, vol. 5, no. 3 September, pp. 687-720.

Manning, C. 1998, Indonesian Labour in Transition, University of Cambridge, Cambridge.

May, T. 1997, Social Research, Open University Press, Bristol.

Milliman, J., Nason, S., Zhu, C. and De Cieri, H. 2002, An exploratory assessment of the purposes of performance appraisals in North and Central America and the Pacific Rim, Asia Pacific Journal of Human Resources, vol. 40, no. 1, pp. 105-121.

Mohrman, S. A. and Lawler, E. E. I. 1997, Transforming the human resource function, Human Resource Management, vol. 36, no. 1, p. 157.

Patton, M. Q. 1990, Qualitative Evaluation and Research Methods, 2nd edn, Sage Publications, Newbury Park, Calif.

Prigogine, I. and Stengers, I. 1985, Order Out of Chaos: Man's New Dialogue with Nature, Flamingo, Hammersmith, London. 
Prigogine, I. and Stengers, I. 1997, The End of Certainty : Time, Chaos, and the New Laws of Nature, 1st Free Press edn, Free Press, New York.

Smilansky, J. 1997, The New HR, 1st edn, International Thomson Business Press, London.

Stacey, R. D. 1996, Complexity and Creativity in Organizations, 1st edn, Berrett-Koehler Publishers, San Francisco.

Stacey, R. D. 2003, Strategic Management and Organization Dynamics: the Challenge of Complexity, 4th edn, Pearson Education Limited, Essex, UK.

Strauss, A. L. and Corbin, J. M. 1990, Basics of Qualitative Research: Grounded Theory Procedures and Techniques, Sage Publications, Newbury Park, Calif.

Thoha, N and Whiteley, A.M, 2005 Linear and NonLinear Systems within the HRM Framework: An Indonesian study, published in ANZAAM Conference Proceedings December, Canberra

Tracey, B. J. and Nathan, A. E. 2002, The strategic and operational roles of human resources: An emerging model, Cornell Hotel and Restaurant Administration Quarterly, vol. 43, no. 4, pp. 17-26.

Truss, C. and Gratton, L. 1994, Strategic human resource management: A conceptual approach, The International Journal of Human Resource Management, vol. 5, no. 3 September, pp. 663-686.

Ulrich, D. 1997, HR of the future: Conclusions and observations, Human Resource Management, vol. 36, no. 1, p. 175.

Vickers, A. 1997, Preface, in R. Goodfellow, (ed.) Indonesian Business Culture, ButterworthHeinemann Asia, Singapore, pp. 1-3.

Wheatley, M. J. 1994, Leadership and the New Science: Learning about Organization from an Orderly Universe, Berrett-Koehler Publishers, Inc., San Francisco, CA.

Whiteley, A. M. 2000a, Grounded research: A modified grounded theory for the business setting, Working Paper 00:02 Graduate School of Business, Curtin University, Perth, Western Australia.

Whiteley, A. M. 2000b, Human Resource Strategy in
Turbulent Environment, in A. Travaglione and V. Marshall, (eds.), Human Resource Strategies: An Applied Approach, The McGraw-Hill Companies, Inc., Sydney, pp. 41-80.

Whiteley, A. M. 2004, Grounded research: A modified grounded theory for the business setting, Qualitative Research Journal, vol. 4, no. 1, pp. 27-46.

Whiteley, A. M., Cheung, S. and Zhang, S. Q. 2000, Human Resource Strategies in China, World Scientific, Singapore.

Yin, R. K. 1994, Case Study Research: Design and Methods, 2nd edn, Sage Publications, Thousand Oaks. 